\title{
Lasten ja nuorten hammashoidon vaiheet ja sisällölliset kehityshaasteet
}

Lasten ja nuorten hammashoidolla on Suomessa pitkät perinteet. Tampereella kansakoululaisten kunnallinen hammashoito aloitettiin vuonna 1909, Turussa 1910 ja Vaasassa 1912. Helsingissä aloite kaupungin kustannuksella tapahtuvasta kansakoululaisten hammashoidosta tehtiin jo vuonna 1893, mutta kaupunginvaltuusto ei asialle syttynyt. Vuonna 1907 eräät yksityiset hammaslääkärit ryhtyivät kuitenkin hoitamaan maksutta kansakoululaisten hampaita perustamassaan yksityisessä kansakouluhammasklinikassa, jonka menoista he henkilökohtaisesti vastasivat. Yksityisen kansakouluhammasklinikan lopetettua toimintansa kunnallinen kouluhammasklinikka perustettiin myös Helsinkiin vuonna 1925. Мyöhemmin kuntien omaehtoisesti järjestämä kansakoululaisten hammashoito levisi pikkuhiljaa muuallekin, mutta maksuttoman hammashoidon ulottumattomiin jäi yhä suuri osa maamme kansakoululaisista siitäkin huolimatta, että koululaisten hammashoitoa oli alettu järjestää myös Mannerheimin lastensuojeluliiton toimesta. Hoitoon sisältyi lähinnä hampaiden paikkausta ja särkevien hampaiden poistamista. Systemaattista hammassairauksia ehkäisevää toimintaa siihen ei sisältynyt.

Laki kansakoulujen hammaslääkärintoimesta säädettiin vuonna 1956 ja sen myötä kansakoululaisten hampaiden tarkastuksesta ja hoidosta tuli kaikkien kuntien lakisääteinen tehtävä vuonna 1957. Käytännössä uudistus näkyi syrjäseuduilla vasta 1960-luvun loppupuolella, sillä lakiin oli säädetty 10 vuoden siirtymäaika. Lakisääteinenkin hammashoito sisälsi aluksi pääasiassa särkevien hampaiden poistamista ja hampaiden paikkausta. Hammassairauksia ehkäisevä toiminta lähti kuitenkin käyntiin jo muutaman vuoden kuluessa. Riittävästi fluoridia sisältävän talousveden kariesvaurioiden syntyä ja etenemistä hillitsevä vaikutus tunnettiin jo ennen lain säätämistä. Fluoridia oli vuonna 1945 ryhdytty tutkimustarkoituksessa lisäämään eräiden yhdysvaltalaisten paikkakuntien vesijohtoveteen, ja vuodesta 1951 lähtien veden fluoridoinnilla oli Yhdysvaltain terveydenhuoltoviranomaisen (U.S Public Health Service) hyväksyntä. Sen innoittamana Kuopion kaupunki aloitti vesijohtoveden fluoridoinnin vuonna 1959. Toimenpiteen vaikutus näkyi pian kariesvaurioiden esiintyvyyden nopeana vähenemisenä. Lääkintöhallituksen ponnekkaista yrityksistä huolimatta yksikään muu kunta ei ryhtynyt fluoridoimaan vesijohtovettään. Niinpä kuntia alettiin ohjata käyttämään muita menetelmiä fluorin hampaiden reikiintymistä ehkäisevän vaikutuksen hyödyntämiseksi. Jo vuonna 1962 kuntia suositeltiin lukukausien aikana järjestämään kansakoululaisille hampaiden purskuttelu natriumfluoridiliuoksella kahden viikon välein. Lääkintöhallituksen fluoriasioita perusteellisesti käsitellyt yleiskirje saatiin vuonna 1969. Fluorihammastahnat olivat tulleet markkinoille 1960-luvun alussa. Ne syrjäyttivät ennen pitkää lähes kokonaan fluoridia sisältämättömät hammastahnat. Sokeristen tuotteiden nauttimisen hampaiden reikiintymiselle altistava vaikutus tunnettiin 1950-luvun puolivälistä lähtien hyvinkin tarkoin, mutta kesti vielä pitkään ennen kuin kariesvaurioita pyrittiin määrätietoisesti torjumaan liiallisen sokerinkäytön vähentämiseen tähtäävällä valistustoiminnalla.

Valtiovallan normiohjaus olisi tuskin yksinään saanut hampaiden reikiintymisen ehkäisytoimintaa hyvään vauhtiin jo ennen 1970-luvun alkua. Asian ripeästä etenemisestä on paljolti kiittäminen Kouluhammaslääkäriyhdistyksen koulutustoimintaa. Mannerheimin lastensuojeluliitolla oli keskeinen rooli erilaisten valistusmateriaalien tuottamisessa. Lisäksi liitto paikallisyhdistyksineen lahjoitti kunnille hammasharjoja koululaisia varten. Kansakoululaisille jaettiinkin 
uskomattoman suuri määrä hammasharjoja ja fluorihammastahnoja, joiden käyttöä harjoiteltiin kouluissa ja hammashoitoloissa. Hampaiden fluoridiliuospurskuttelut saatiin jo 1960-luvun puolella käyntiin useiden kuntien kansakouluilla.

Kouluhammashoidon heikkoutena oli, että se alkoi lasten hammasterveyden ylläpitämisen kannalta liian myöhäisellä iällä. Monien kansakoulun aloittavien lasten hampaat olivat perin huonossa kunnossa. Sanomalehtitietojen mukaan joka viidennellä kolmivuotiaalla ja joka kolmannella kuusivuotiaalla oli ikenien tasalle tuhoutuneet hampaat 1960-luvun päättyessä. Vuonna 1972 säädetyn Kansanterveyslain myötä maamme perusterveydenhuollon rakenteet ja toimintatavat uudistuivat perusteellisesti. Sen seurauksena kansakoululaisten maksuton hammashoito laajeni lyhyehkön siirtymäajan jälkeen koskemaan kaikkia 0-16-vuotiaita. Niin lääkintöhallitus kuin lääninhallituksetkin järjestivät lain toteutukseen liittyvää koulutusta. Kouluhammaslääkäriyhdistyksen perinteitä jatkavalla Terveyskeskushammaslääkäriyhdistyksellä oli kuitenkin keskeinen merkitys sellaisten käytännön toimien puolestapuhujana, joita tarvittiin hammassairauksien ehkäisyohjelmien suunnitteluun ja toteutukseen. Pian hampaiden reikiintymisen ehkäisemiseksi tehtiin ennennäkemättömän ponnekasta valistustyötä niin neuvoloissa, hammashoitoloissa kuin kouluissakin. Hampaiden harjaus fluorihammastahnalla ja suunterveyden kannalta terveelliset ruokatottumukset olivat elintapaohjauksen keskiössä. Alle kouluikäisille suositeltiin ja jaettiin natriumfluoriditabletteja, joiden tuolloin uskottiin vahvistavan puhkeamattomia hampaita puhkeamisen jälkeen uhkaavia kariesbakteerien aiheuttamia happohyökkäyksiä vastaan. Koululaisten hampaiden fluoridiliuospurskuttelut saatiin käyntiin kautta koko maan. Ksylitolituotteiden tulo markkinoille auttoi omalta osaltaan taistelussa hampaiden reikiintymistä vastaan. Suunterveyden ammattihenkilöt saivat käyttöönsä entistä tehokkaampia reikiintymisen kliinisiä ehkäisymenetelmiä, ennen muuta fluoridilakat ja hampaiden purupintojen muovipinnoitteet. Tuloksia alkoi näkyä yllättävän nopeasti. Aiemmin voimakkaassa kasvussa ollut makeisten myynti kääntyi laskuun, samoin karieksen vaurioittamien hampaiden lukumäärän keskiarvo lasta kohti. Myöhemmin ilmeni, että lasten hampaiden reikiintyminen oli vähentynyt voimakkaasti kautta koko teollistuneen maailman siitä riippumatta, minkälaisin keinoin reikiintymistä oli eri maissa yritetty torjua. Kansainvälinen asiantuntijapaneeli päätyi sittemmin uskomaan, että kariestilanteen paranemisesta oli ensisijaisesti kiittäminen fluorihammastahnan käytön yleistymistä.

Suomessa hampaiden reikiintymisen ehkäisemiseen tähtäävän valistustoiminnan määrä ja intensiteetti heikkenivät selvästi 1980-luvulla sitä mukaa kuin lasten ja nuorten hammastilanne parani. Tämä näkyi makeisten myynnin kääntymisenä uuteen nousuun. Hampaiden fluoridiliuospurskutteluista kouluilla luovuttiin. Samaan aikaan hampaiden purupintojen uurteiden pinnoittaminen ja fluoridilakkakäsittelyt lisääntyivät hallitsemattomasti. Niiden hyödyllisyyttä ymmärrettiin arvioida kriittisesti vasta 1990-luvulla. Tuolloin syvä lama pakotti kunnat rajuihin säästötoimiin, jotka merkitsivät vakavaa takaiskua kunnalliselle terveyden edistämistyölle. Myös fluoridilakkausten ja pinnoitteiden määrät kääntyivät jyrkkään laskuun. Sen seurauksena ei kuitenkaan ollut kariesvaurioiden ilmaantuvuuden nousu, mikä paljasti näiden toimenpiteiden vähäisen rajahyödyn tuolloisissa oloissa. Valtaosa fluoridilakkakäsittelyistä ja pinnoitteista oli tehty sellaisille lapsille ja nuorille, jotka eivät olisi olleet niiden tarpeessa. Vuonna 1992 Kuopion kaupunki lopetti myös juomaveden fluoridoinnin, mutta siitäkin selvittiin ilman että kariesvaurioiden esiintyvyys olisi kääntynyt nousuun. 1990-luvulla lasten ja nuorten hampaiden reikiintymisen vähenemisvauhti kuitenkin tasaantui, mutta niin olisi todennäköisesti käynyt, vaikka kuntien säästötoimet eivät olisikaan kohdistuneet hampaiden reikiintymistä ehkäiseviin toimenpiteisiin.

Tuoreimpien THL:n Sotkanetissä julkaistujen tilastotietojen mukaan pysyviltä hampailtaan terveiden 12-vuotiaiden prosenttiosuus on Suomessa runsaat $60 \%$. Noin viidellä prosentilla tämän ikäisistä tarkastetuista on enemmän kuin kaksi paikkaushoitoa vaativaa kariesvauriota. Terveys 2011 -tutkimuksessa 30 vuotta täyttäneillä miehillä oli keskimäärin 0,7 ja naisilla 0,3 paikkaushoidon tarpeessa olevaa hammasta. Näiden lukujen valossa hampaiden paikkaushoidon tarpeen ei odottaisi olevan kovin suuri. Hampaan paikkaus on kuitenkin edelleen yleisin yksittäinen toimenpide Suomen suunterveyden- 
huollossa. Hampaan paikkaushoidon vuonna 2019 julkaistua Käypä hoito -suositusta valmistelleen työryhmän selvitysten mukaan maamme perusterveydenhuollossa ja yksityisellä sektorilla tehdään vuosittain yhteensä yli kolme miljoonaa paikkaushoitotoimenpidettä. Hammaslääkärin työajasta 30-50 \% kuluu hampaiden paikkaukseen. Paikkaushoidon suuri tarve johtuu siitä, että hammaspaikkoja joudutaan vuosien varrella toistuvasti korjailemaan tai uusimaan, mistä aiheutuu paljon kustannuksia. Sitä paitsi paikkojen korjailu heikentää ajan mittaan hampaita. Paikkaustarpeen vähentäminen onkin Suomen suunterveydenhuollon palvelujärjestelmän keskeisimpiä sisällöllisiä kehityshaasteita. Paikatun hampaan myöhemmän ylläpitohoidon tarpeeseen on vaikeata vaikuttaa. Siksi ensisijaisena keinona on ennestään paikkaamattomien hammaspintojen reikiintymisen ehkäiseminen.

Suomalaislasten keskimääräinen hammastilanne on hiljalleen kohentunut aivan viime vuosinakin. Vuosien 2012 ja 2018 välillä pysyviltä hampailtaan terveiden 12-vuotiaiden prosenttiosuus nousi $54 \%$ :sta $62 \%$ :iin. Nykyoloissa jälkimmäistäkään lukemaa ei kuitenkaan ole lupa pitää tyydyttävänä. Esimerkiksi Tanskassa lasten ja nuorten hammasterveys on selvästi parempi. On turvallista olettaa, että suomalaislasten kariestilanne paranisi nykyistä ripeämmin, jos heidän suuhygienia- ja ruokatottumuksensa saataisiin muuttumaan terveellisemmiksi. Hampaitaan suomalaiset lapset harjaavat keskimäärin selvästi harvemmin kuin niitä harjataan Suomen kaltaisissa OECD-maissa. Tilanne on vuosien varrella parantunut, mutta kovin hitaasti. WHO:n koululaistutkimuksen mukaan 11-vuotiaista suomalaispojista $33 \%$ harjasi hampaansa suositusten mukaisesti vähintään kahdesti päivässä lukuvuonna 2001/2002. Kahtatoista vuotta myöhemmin (2013/2014) osuus oli noussut $53 \%$ :iin. Tytöillä vastaavat osuudet olivat $47 \%$ ja $66 \%$. Vertailuissa mukana olleiden maiden keskiarvot olivat samassa ajassa kasvaneet $56 \%$ :sta $62 \%$ :iin (pojat) ja $67 \%$ :sta $72 \%$ :iin (tytöt). Vertailujen kärjessä oli kumpanakin lukuvuonna Sveitsi, jossa vastaavat osuudet kasvoivat $81 \%$ :sta $85 \%$ :iin (pojat) ja $86 \%$ :sta $89 \%:$ :iin (tytöt). Suomalaislasten hampaiden harjauksen vähäisyys näyttää olevan kulttuurinen erityispiirre, jonka muuttaminen edellyttää pitkäjänteistä monialaista yhteistyötä. Erityisesti tämä koskee poikia, jotka ovat saaneet tämän piirteen sosiaalisena perintönä isiltään. Terveys 2011-tutkimuksessa vain $53 \% 30$ vuotta täyttäneistä miehistä ilmoitti harjaavansa hampaansa vähintään kaksi kertaa päivässä. Naisilla vastaava osuus oli $81 \%$.

Myös lasten ja nuorten ruokatottumuksissa on piirteitä, jotka altistavat heidät hampaiden reikiintymiselle. Kariesbakteereille ravinnoksi kelpaavien tuotteiden napostelua tapahtuu yleisesti säännöllisten aterioiden välillä, samoin sokeristen ja happamien juomien toistuvaa siemailua. Voimassa olevien kansallisten ravitsemussuositusten mukaan lisätyn sokerin saannin ei tulisi ylittää 10 prosenttia kokonaisenergiansaannista. Aikuisilla keskimääräinen saanti ei ylitä tätä rajaa, mutta 2-6-vuotiailla ja teini-ikäisillä suositeltu yläraja ylittyy selvästi. Olemme muiden OECD-maiden kanssa suunnilleen samanlaisessa tilanteessa ruokatottumuksiin ja ravitsemukseen liittyvien hammasterveyden uhkien suhteen. Tämä ei kuitenkaan merkitse, että näihin uhkiin olisi lupa suhtautua välinpitämättömästi.

On ilmeistä, että lasten ja nuorten hammasterveyden kohenemisen vauhtia ei saada merkittävästi paranemaan ilman että karieksen hallinnan painopistettä siirretään hammashoitoloissa tehtävistä kliinisistä toimenpiteistä sellaiseen terveysohjaukseen, jonka lähtökohtana on luottamus ihmisten omiin mahdollisuuksiin ylläpitää suunterveyttään. Mallia sopii ottaa 1970-lukulaisesta sitoutuneisuudesta hammasterveyden parantamiseen valistuksen keinoin, mutta paternalistinen lähestymistapa ei ole oikea vastaus tämän päivän haasteisiin. Sen sijaan meidän on opittava näkemään lapset ja nuoret sekä heidän perheensä kumppaneina ja tärkeänä terveyden edistämisen voimavarana. Keskeisimmäksi tavoitteeksi tulee ottaa vähintään kahdesti päivässä hampaansa harjaavien lasten ja nuorten prosenttiosuuden kasvu selvästi nykyistä korkeammalle tasolle. Tuloksena eivät ole pelkästään aiempaa puhtaammat hampaat, mikä on jo sinänsä tärkeää sekä karieksen hallinnan että parodontaalisairauksien torjunnan kannalta. Riittävän usein tapahtuva vähintään kahden minuutin ajan kestävä hampaiden harjaus on myös edellytys sille, että fluorihammastahnan kariesvaurioiden syntyä ja etenemistä hillitsevä vaikutus saadaan hyödynnettyä täysimääräisesti. 
Terveelliset elintavat juurtuvat helpoiten varhaislapsuudessa. Siksi hampaiden harjaukseen liittyvä terveysohjaus on erityisen tärkeää äitiysja lastenneuvoloissa, joiden tulisi voida toimia tiiviissä yhteistyössä suunterveydenhuollon kanssa. Hampaiden harjauksen toistuvan puheeksi ottamisen ja sen tärkeyden korostamisen pitäisi kuulua neuvoloiden arkirutiineihin. Suunterveyden ammattihenkilöiden asiana on antaa ohjausta kulloisessakin iässä sopivan hammasharjan ja fluorihammastahnan valinnassa sekä niiden käyttämisessä. Tuekseen neuvoloiden ja suunterveydenhuollon toteuttama suuhygienian tehostamiseen tähtäävä terveysohjaus tarvitsee näkyvää kampanjointia eri medioissa, sosiaalisia medioita unohtamatta. Päivähoidon ja varhaiskasvatuksen tulisi omalta osaltaan tukea lasten huoltajia heidän ponnisteluissaan aamuin ja illoin tapahtuvan hampaiden harjauksen juurruttamiseksi luonnolliseksi osaksi lasten jokapäiväistä elämää. Myös ruokatottumusten terveellisyyteen tähtäävä terveysohjaus edellyttää monialaista yhteistyötä. Sille on nykyisin hyvät edellytykset, sillä eri väestöryhmille suunnatuissa suomalaisissa ravitsemus- ja ruokailusuosituksissa ruokatottumuksiin liittyvät suunterveyden uhkat on otettu huomioon erittäin hyvin.

Neuvoloiden terveysohjaus ei tavoita sellaisia ohjauksen tarpeessa olevia lapsia ja nuoria, jotka eivät ole kouluikään mennessä omaksuneet hyviä suuhygienia- ja ruokatottumuksia. Vastuu heidän tunnistamisestaan kuuluu terveyskeskusten hammashoitoloille. Puutteellinen suuhygienia on helppo havaita määräaikaisissa hammastarkastuksissa siitä riippumatta, minkälainen koulutus tarkastuksen suorittajalla on. Jos tarkastuksessa havaitaan hampaiden reikiintymistä tai merkkejä alkavista kariesvaurioista, on lisäksi selvitettävä epäterveellisten ruokatottumusten mahdollinen osuus vaurioiden syntyyn. Tilaisuus hampaiden pinnoille kertyvien bakteeripeitteiden poistamisen ohjattuun harjoitteluun on tarjottava kaikille sellaista tarvitseville lapsille ja nuorille. Sama koskee ohjausta terveellisiin ruokatottumuksiin, joiden kulmakivinä ovat säännöllinen ateriarytmi ja veden käyttäminen janojuomana sekä se, että aterioiden välillä tapahtuvaa napostelua ja sokeristen tai happamien juomien toistuvaa siemailua vältetään.

Jos maksuttoman hammashoidon jättävä 17vuotias on tervehampainen, noudattaa hyvää suuhygieniaa sekä syö ja juo kohtalaisen terveellisesti, hänellä on erinomaiset lähtökohdat hyvän suunterveyden ylläpitämiseen myös aikuisiässä. Lasten ja nuorten suunterveydenhuollossa tavoitteeksi tulisi ottaa tällaisten 17-vuotiaiden mahdollisimman suuri osuus maksullisen aikuishammashoidon piiriin siirtyvistä.

\section{Hannu Hausen}

HLT, EHL, MPH

Sosiaalihammaslääketieteen emeritusprofessori, Oulun yliopisto, Suun terveyden tutkimusyksikkö

Terveyden edistämisen asiantuntija,

Suomen Hammaslääkäriliitto ry

Suun terveydenhuollon lääketieteellinen

neuvonantaja, Nordic Healthcare Group

Kirjoitus pohjautuu Terveydenhuoltolääkrit ry:n jakaman Terveydenhuoltopalkinnon vastaanottamistilaisuudessa pidettyyn kiitospuheeseen Terveydenhuoltotutkimuksen päivillä 7.11.2019 Tampereella. 